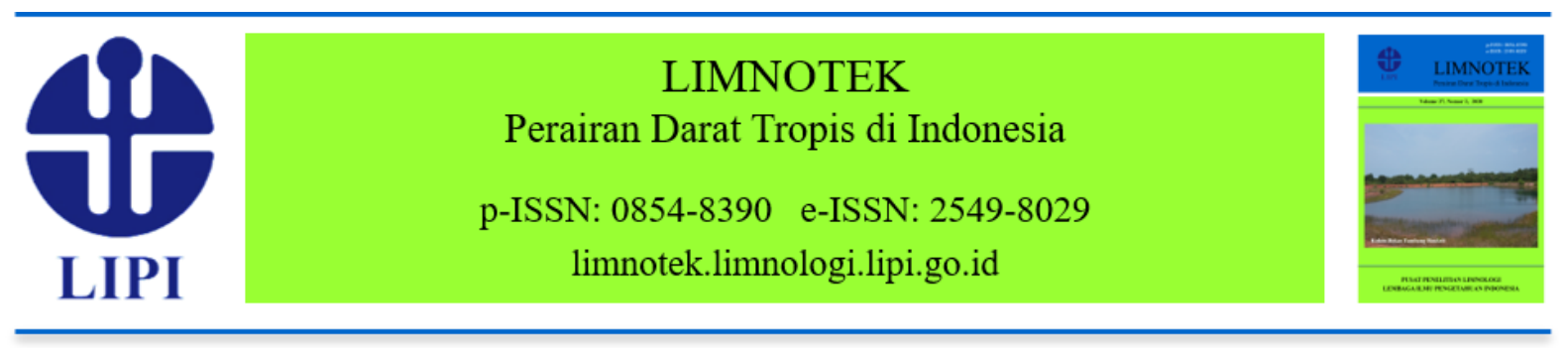

\title{
Studi Fitoremediasi Serapan Besi (Fe) dari Kolam Bekas Tambang Bauksit Menggunakan Purun (Eleocharis sp.)
}

\author{
Shela Novayanti Wulan, Tri Apriadi, Winny Retna Melani
}

Fakultas Ilmu Kelautan dan Perikanan, Universitas Maritim Raja Ali Haji, Tanjung Pinang

Email: shelanovayantiwulan@gmail.com

Diajukan 30 Januari 2019. Ditelaah 5 November 2019. Disetujui 2 Agustus 2020.

\begin{abstract}
Abstrak
Kolam bekas tambang bauksit di Kelurahan Senggarang, Kota Tanjung Pinang memiliki kandungan besi yang meskipun masih di bawah ambang batas baku mutu, namun berpotensi mengalami biomagnifikasi logam besi. Selain mengandung besi, kolam bekas tambang bauksit tersebut banyak ditumbuhi oleh tumbuhan mencuat yaitu purun (Eleocharis sp.). Air kolam bekas tambang bauksit juga dimanfaatkan warga sekitar untuk mandi dan mencuci. Tujuan penelitian ini yaitu untuk mengetahui kemampuan purun menyerap besi (Fe) dari air kolam bekas tambang bauksit di Kota Tanjung Pinang. Penelitian dilakukan melalui eksperimen di laboratorium menggunakan rancangan acak lengkap terhadap biomassa purun yang berbeda, yaitu $250 \mathrm{~g}, 500 \mathrm{~g}$, dan $0 \mathrm{~g}$ (kontrol) selama 30 hari. Penelitian ini menunjukkan perbedaan yang nyata antara perlakuan biomassa purun $250 \mathrm{~g}$ dan $500 \mathrm{~g}$ dalam menyerap besi dari hari ke-0 hingga hari ke-30. Biomassa purun $500 \mathrm{~g}$ mampu menyerap besi sebesar $80,1 \%$, sedangkan kemampuan penyerapan besi biomassa purun $250 \mathrm{~g}$ hanya $17,1 \%$. Penelitian ini mengonfirmasi bahwa akar purun lebih efektif dalam menyerap dan menyimpan logam besi daripada bagian batang.
\end{abstract}

Kata kunci: fitoremediasi, besi (Fe), purun (Eleocharis sp.), tambang bauksit, Tanjung Pinang

\section{Abstract}

Phytoremediation Study of Iron (Fe) Absorption from Former Bauxite Mine Ponds Using Hairgrass (Eleocharis sp.). The former bauxite mining ponds in Senggarang Village, Tanjung Pinang City showed iron content which, although still below the permitted threshold, has the potential to experience metal iron biomagnification. In addition to containing iron, these former bauxite mining ponds are overgrown with emergent aquatic plants, such as hairgrass (Eleocharis sp.). The water from these ponds is also used by local residents for bathing and washing. The purpose of this study was to determine the ability of hairgrass to absorb iron $(\mathrm{Fe})$ from bauxite mining pond water in Tanjung Pinang City. The research was conducted through 
laboratory experiments using a completely randomized design method on different hairgrass biomass, i.e. $250 \mathrm{~g}, 500 \mathrm{~g}$, and $0 \mathrm{~g}$ (control) for 30 days. This study showed a significant difference between the treatment of hairgrass biomass of $250 \mathrm{~g}$ and of $500 \mathrm{~g}$ in absorbing iron from day 0 to day 30. The hairgrass biomass of $500 \mathrm{~g}$ was able to absorb iron up to $80.1 \%$, while the iron absorption capacity of $250 \mathrm{~g}$ of hairgrass biomass was only $17.1 \%$. This study confirmed that hairgrass roots were more effective at absorbing and storing ferrous metals than the stems.

Keywords: phytoremediation, iron (Fe), hairgrass (Eleocharis sp.), bauxite mine, Tanjung Pinang

\section{Pendahuluan}

Penambangan bauksit merupakan salah satu kegiatan pertambangan utama di Pulau Bintan. Menurut Badan Pusat Statistik Daerah Kota Tanjung Pinang (2018), secara geologis Pulau Bintan mengandung bauksit dengan keasaman tinggi. Pulau Bintan diketahui memiliki cadangan bauksit sejak tahun 1924 oleh pemerintah Hindia Belanda (Rohmana et al., 2007). Kegiatan penambangan bauksit mulai dihentikan pada tahun 2013 oleh Pemerintah Kota Tanjung Pinang berdasarkan Undang-Undang Nomor 4 Tahun 2009 tentang Pertambangan Mineral dan Batubara (Mohari, 2013). Namun, aktivitas penambangan yang saat ini sudah terhenti masih memberikan dampak pada lingkungan. Perubahan lingkungan bekas penambangan terlihat dari kondisi lahan bekas tambang yang terbuka dan cekungancekungan yang terbentuk berubah menjadi kolam-kolam yang terisi air hujan (Kusmanto et al., 2019). Kolam-kolam bekas tambang tersebut dimanfaatkan oleh warga sekitar untuk mandi dan mencuci, meskipun kemungkinan masih menyisakan kandungan bahan pencemar. Menurut penelitian Zulfikar et al. (2015), kandungan logam berat tertinggi di kolam bekas tambang bauksit di Sungai Carang, Kota Tanjung Pinang, adalah besi, sebesar 0,61$1,45 \mathrm{ppm}$.

Besi merupakan makromineral bumi hasil pelapukan batuan bauksit (Rohmana et al., 2007). Kehadiran besi penting sebagai unsur mikrobiologi (Nurhaini \& Affandi,
2016). Selain itu, besi sebagai unsur penting dibutuhkan oleh makhluk hidup dalam jumlah yang sedikit (Palar, 2008). Besi merupakan salah satu logam essensial yang berfungsi dalam proses biokimia dan fisiologis bagi tumbuhan dan hewan (Nagajyoti et al., 2010). Konsentrasi besi yang berlebihan dapat menimbulkan efek toksisitas pada makhluk hidup, misalnya pada jaringan daun tumbuhan (Becker \& Asch, 2005). Besi yang berasal dari aktivitas penambangan apabila terlarut dalam air dengan kadar yang melebihi 1 $\mathrm{mg} / \mathrm{L}$ dan terakumulasi dalam tubuh manusia dapat mengakibatkan gangguan kesehatan (Nurhaini \& Affandi, 2016), seperti keracunan dengan gejala mulai dari mual dan muntah hingga dinding usus mengalami pendarahan pada fase lanjut (Ainiyah et al., 2018). Logam besi yang terakumulasi dalam tubuh organisme akuatik seperti ikan masuk melalui air, sedimen, dan rantai makanan (Herliyanto et $a l .$, 2014). Logam besi yang terakumulasi tersebut dapat mengganggu aktivitas fisiologis organisme akuatik (Effendi, 2003). Efek toksisitas besi berdampak pada jaringan insang, sehingga mengganggu respirasi, serta menurunkan pertumbuhan dan perkembangan organisme akuatik (Cadmus et al., 2018; Herliyanto et al., 2014).

Tumbuhan yang hidup di kolam bekas tambang bauksit menjadi tumbuhan pionir yang mampu meremediasi bahan pencemar, di antaranya purun (Aryani \& Apriadi, 2018; Polprasert (1989) dalam Khiatuddin, 2003). Asikin dan Thamrin (2012) 
menyebutkan bahwa Eleocharis dulcis merupakan tumbuhan gulma yang hidup di tanah yang mengandung asam sulfat dengan pH 3 dan berfungsi sebagai sumber bahan organik serta biofilter yang menyerap unsur beracun atau logam berat seperti besi $(\mathrm{Fe})$. Oleh karena itu, penelitian ini yang bertujuan untuk mengetahui seberapa besar kemampuan purun dalam menyerap besi (Fe) dari kolam bekas tambang bauksit di Kelurahan Senggarang sangat diperlukan. Hasil penelitian ini diharapkan dapat menjadi sumber informasi dan acuan pengelolaan kolam bekas tambang bauksit pada masa yang akan datang.

\section{Bahan dan Metode}

\section{Waktu dan Tempat Penelitian}

Penelitian ini dilakukan pada bulan April-Desember 2018. Sampel tumbuhan purun (Eleocharis sp.), sedimen bauksit, dan air diambil dari kolam bekas tambang bauksit di Sengarang, Kota Tanjung Pinang. Penelitian utama dilakukan di Laboratorium Fakultas Ilmu Kelautan dan Perikanan, Universitas Maritim Raja Ali Haji, Kota Tanjung Pinang.

\section{Prosedur Penelitian}

Sebelum penelitian utama dilakukan, sampel tumbuhan purun diambil dari tujuh kolam bekas tambang bauksit selama kurun waktu tiga minggu dengan berat total $\pm 2,5$ $\mathrm{kg}$. Sampel tumbuhan purun diaklimatisasi berupa penyesuaian lingkungan hidup dengan ditanam di dalam bak fiber dan plastik yang berisi lumpur bauksit dan air selama tiga minggu di laboratorium.

Penelitian utama dilakukan selama 30 hari menggunakan biomassa tumbuhan purun $250 \mathrm{~g}$ dan $500 \mathrm{~g}$ dengan tinggi ratarata $6 \mathrm{~cm}$. Purun ditumbuhkan dalam media sedimen yang mengandung lumpur bekas tambang bauksit setinggi $10 \mathrm{~cm}$, dan air yang berasal dari kolam bekas tambang bauksit dengan ketinggian $6 \mathrm{~cm}$. Media tersebut ditempatkan di dalam bak plastik berdiameter $40 \mathrm{~cm}$ dan tinggi $20 \mathrm{~cm}$.
Penelitian dilakukan dengan metode eksperimental Rancangan Acak Lengkap (RAL), yang terdiri dari tiga perlakuan variasi biomassa purun, yaitu $0 \mathrm{~g}$ (kontrol, K), $250 \mathrm{~g}$ (Perlakuan 1, P1), dan $500 \mathrm{~g}$ (Perlakuan 2, P2). Setiap perlakuan diulang sebanyak tiga kali, sehingga diperoleh sembilan unit bak penelitian yang disusun secara acak (Gambar 1).

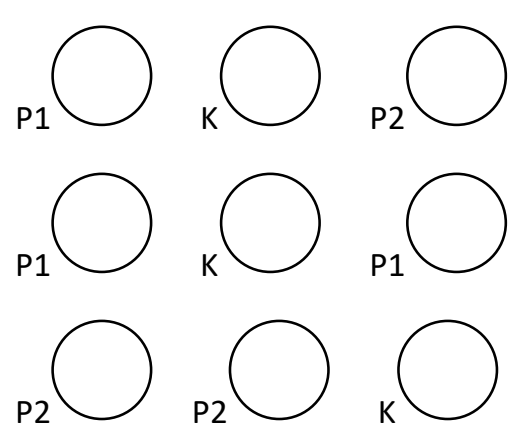

Gambar 1. Tata letak bak penelitian

Percobaan dilakukan menggunakan fitoremediasi statis, yaitu fitoremediasi dalam keadaan tidak mengalir. Bak-bak penelitian diletakkan di tempat yang terlindung dari sinar matahari langsung dengan intensitas cahaya sebesar 963,6 \pm 296,5 lux. Selama 30 hari percobaan, parameter fisika dan kimia air berupa suhu, oksigen terlarut (DO), dan $\mathrm{pH}$ diukur setiap hari dengan tiga kali pengulangan menggunakan Portable Multi-Parameter Meter and Probe (Senso Direct 150 Lovibond $($ ).

Preparasi sampel purun, sampel air, dan sedimen lumpur bauksit dilakukan pada awal dan akhir penelitian untuk menentukan konsentrasi besi. Preparasi sampel purun dan sedimen lumpur bauksit menggunakan metode destruksi basah. Sebanyak $100 \mathrm{~g}$ sampel purun yang terdiri dari akar dan batang tumbuhan dibilas dengan akuades dan akuabides, lalu dipotong-potong hingga kecil, kemudian dikeringkan di dalam oven pada suhu $80^{\circ} \mathrm{C}$ selama 48 jam. Setelah kering, sampel dihaluskan. Serbuk halus sampel sebanyak 1 g dimasukkan ke dalam erlenmeyer 250 $\mathrm{mL}$, lalu ditambahkan $\mathrm{HNO}_{3}$ dan akuades dengan perbandingan 1:5. Sampel 
dipanaskan pada suhu $100-150^{\circ} \mathrm{C}$ selama 40 menit, lalu dibiarkan dingin pada suhu ruang. Sampel dipanaskan kembali dengan menambahkan $\mathrm{HNO}_{3}$ pekat dan $\mathrm{HCl}$ dengan perbandingan 3:5 selama 20-30 menit hingga larutan hampir kering. Sampel didinginkan pada suhu ruang, lalu akuades ditambahkan sebanyak $100 \mathrm{~mL}$ dan larutan disaring dengan kertas saring berukuran pori $0,45 \mu \mathrm{m}$ dan berdiameter $47 \mathrm{~mm}$ (modifikasi dari Amelia, 2015; Ariyani et al., 2014; AOAC, 1990). Pengukuran konsentrasi besi dalam sampel purun dilakukan di Balai Teknik Kesehatan Lingkungan dan Pengendalian Penyakit (BTKLPP) Kelas 1 Batam menggunakan alat Atomic Absorption Spectrophotometer (AAS) Shimadzu AA-7000. Pengukuran dilakukan pada hari ke-0 dan hari ke-30 untuk mengetahui tingkat penyerapan besi (Fe) oleh purun setelah 30 hari.

Untuk sedimen lumpur bauksit, sebanyak $100 \mathrm{~g}$ sampel dikeringkan dalam oven pada suhu $60^{\circ} \mathrm{C}$ selama 96 jam hingga berat konstan. Sebanyak $1 \mathrm{~g}$ sampel dimasukkan ke dalam erlenmeyer, lalu ditambahkan $25 \mathrm{~mL}$ aquaregia dengan perbandingan $\mathrm{HCl}$ dan $\mathrm{HNO}_{3}$ sebesar 3:1. Sampel dipanaskan pada suhu $\pm 100^{\circ} \mathrm{C}$ selama 15 menit sampai larut, lalu $20 \mathrm{~mL}$ akuades ditambahkan dan dipanaskan lagi selama 14-30 menit, kemudian sampel didinginkan pada suhu ruang. Akuades sebanyak $100 \mathrm{~mL}$ ditambahkan pada sampel, kemudian sampel disaring menggunakan kertas saring berukuran pori $0,45 \mu \mathrm{m}$ dan berdiameter $47 \mathrm{~mm}$ (Amrin \& Ardila, 2013; Kurniawati et al., 2012). Konsentrasi besi dalam sedimen lumpur bauksit diukur dengan Atomic Absorption Spectrophotometer (AAS) Shimadzu AA7000.

Untuk mengukur konsentrasi besi dalam sampel air, sebanyak $\pm 100 \mathrm{~mL}$ air diambil dari kolam bekas tambang bauksit dan dimasukkan ke dalam botol sampel. Sampel diawetkan dengan menambahkan $\mathrm{HNO}_{3}$ pekat hingga $\mathrm{pH}<2$ dan didinginkan (Sudiyani et al., 2011; APHA, 1999; SNI 6989.4:2009 untuk Fe). Konsentrasi besi dalam sampel air juga diukur dengan Atomic Absorption Spectrophotometer (AAS) Shimadzu AA-7000.

\section{Analisis Data}

Analisis data konsentrasi besi dalam sampel menggunakan software SPSS Statistic 22 untuk uji F analisis varian Anova dengan selang kepercayaan $95 \%$. Jika nilai menunjukkan perbedaan penyerapan besi $(\mathrm{Fe})$, maka dilakukan uji lanjutan Beda Nyata Terkecil (BNT) atau Least Significant Difference (LSD).

Penghitungan efektivitas penyerapan yang bertujuan untuk mengetahui tingkat kemampuan purun menyerap besi selama 30 hari perlakuan juga dilakukan. Efektivitas penyerapan (EP) $\mathrm{Fe}$ oleh tumbuhan purun dihitung dengan membandingkan peningkatan konsentrasi besi di dalam tumbuhan dengan penurunan konsentrasi besi di luar tumbuhan (modifikasi dari Prayudi, 2015), sebagai berikut:

$\mathrm{EP}=\frac{[\mathrm{Fe}]_{\mathrm{t}}-[\mathrm{Fe}]_{0} \text { dalam tumbuhan purun }}{[\mathrm{Fe}]_{0}-[\mathrm{Fe}]_{\mathrm{t}} \text { dalam media tanam }} \times 100$

Keterangan:

$\mathrm{EP}=$ efektivitas penyerapan

$[\mathrm{Fe}]_{\mathrm{t}}=$ konsentrasi Fe pada hari ke-30

$[\mathrm{Fe}]_{0}=$ konsentrasi Fe pada hari ke-0

\section{Hasil}

Kedua perlakuan, yaitu biomassa purun $250 \mathrm{~g}$ dan $500 \mathrm{~g}$ memperlihatkan peningkatan konsentrasi besi dalam sampel purun pada hari ke-30. Konsentrasi besi yang diserap oleh biomassa purun $500 \mathrm{~g}$ yaitu $80,1 \%$, sedangkan yang diserap oleh biomassa purun $250 \mathrm{~g}$ yaitu sebesar $17,1 \%$ (Tabel 1). Berdasarkan hasil analisis uji statistik Anova, perlakuan biomassa purun $250 \mathrm{~g}$ dan $500 \mathrm{~g}$ memperlihatkan perbedaan yang nyata dalam menyerap besi selama 30 hari penelitian. 
Tabel 1. Penyerapan besi oleh purun

\begin{tabular}{ccccc}
\hline \multirow{2}{*}{ Perlakuan } & \multicolumn{3}{c}{ Konsentrasi besi (mg/kg) } & Persentase \\
\cline { 2 - 4 } & Awal & Akhir & Diserap & penyerapan (\%) \\
\hline Biomassa purun 250 g & $68,3 \pm 0,002$ & $80,0 \pm 0,005$ & $11,7 \pm 0,003$ & $17,1^{\mathrm{a}}$ \\
Biomassa purun 500 g & $68,3 \pm 0,002$ & $123,0 \pm 0,006$ & $54,7 \pm 0,004$ & $80,1^{\mathrm{b}}$ \\
\hline
\end{tabular}

Keterangan: angka yang diikuti oleh huruf yang berbeda menunjukkan perbedaan nyata pada signifikansi $95 \%$

Tabel 2. Konsentrasi besi terlarut dalam air

\begin{tabular}{ccccc}
\hline \multirow{2}{*}{ Perlakuan } & \multicolumn{3}{c}{ Konsentrasi besi (mg/L) } & \multirow{2}{*}{$\begin{array}{c}\text { Persentase } \\
\text { pelarutan }(\%)\end{array}$} \\
\cline { 2 - 4 } & Awal & Akhir & Terlarut & 1,16 \\
Bak K & $0,068 \pm 0,002$ & $0,147 \pm 0,028$ & $0,079 \pm 0,026$ & 4,21 \\
Bak P1 & $0,068 \pm 0,002$ & $0,354 \pm 0,157$ & $0,286 \pm 0,156$ & \\
Bak P2 & $0,068 \pm 0,002$ & $1,144 \pm 0,293$ & $1,076 \pm 0,292$ & 15,82 \\
\hline
\end{tabular}

Tabel 3. Konsentrasi besi dalam sedimen bauksit

\begin{tabular}{ccccc}
\hline \multirow{2}{*}{ Perlakuan } & \multicolumn{3}{c}{ Konsentrasi besi $(\mathrm{mg} / \mathrm{kg})$} & \multirow{2}{*}{$\begin{array}{c}\text { Persentase } \\
\text { pelepasan }(\%)\end{array}$} \\
\cline { 2 - 4 } & Awal & Akhir & Terlepas & 23,58 \\
Bak K & $12.610,3 \pm 0,2$ & $9.637,5 \pm 0,1$ & $2.973,8 \pm 0,1$ & 1,92 \\
Bak P1 & $12.610,3 \pm 0,2$ & $12.368,0 \pm 0,2$ & $242,30 \pm 0,02$ & 5,71 \\
Bak P2 & $12.610,3 \pm 0,2$ & $11.890,3 \pm 0,5$ & $720,0 \pm 0,3$ & \\
\hline
\end{tabular}

Tabel 4. Efektivitas penyerapan besi oleh purun

\begin{tabular}{cccc}
\hline Perlakuan & $\begin{array}{c}\text { Konsentrasi besi } \\
\text { yang terlepas dari } \\
\text { sedimen }(\mathrm{mg} / \mathrm{kg})\end{array}$ & $\begin{array}{c}\text { Konsentrasi besi } \\
\text { yang diserap } \\
\text { purun }(\mathrm{mg} / \mathrm{kg})\end{array}$ & $\begin{array}{c}\text { Efektivitas } \\
\text { penyerapan } \\
(\%)\end{array}$ \\
\hline Biomassa purun 250 g & 242,3 & 11,7 & 4,8 \\
Biomassa purun 500 g & 720,0 & 54,7 & 7,6 \\
\hline
\end{tabular}

Hasil pengukuran konsentrasi besi $(\mathrm{Fe})$ terlarut dalam media tanam, yaitu air dan sedimen lumpur bauksit diperlihatkan dalam Tabel 2 dan Tabel 3. Konsentrasi rata-rata besi dalam air bak kontrol (K), bak purun $250 \mathrm{~g}(\mathrm{P} 1)$, dan bak purun $500 \mathrm{~g}$ (P2) mengalami peningkatan pada hari ke-30 dibandingkan hari ke-0 (Tabel 2). Pada hari ke-15 dilakukan penambahan akuabides agar kelangsungan hidup purun tetap terjaga selama penelitian. Tabel 3 memperlihatkan konsentrasi besi $(\mathrm{Fe})$ dalam sedimen lumpur bauksit di bak kontrol (K), bak P1, dan bak P2 mengalami penurunan pada hari ke-30 dibandingkan hari ke-0. Hasil penghitungan efektivitas penyerapan besi $(\mathrm{Fe})$ oleh purun ditunjukkan dalam Tabel 4. Selama 30 hari perlakuan, biomassa purun $500 \mathrm{~g}$ memperlihatkan efektivitas penyerapan sebesar 7,6\%, sedangkan efektivitas penyerapan oleh biomassa $250 \mathrm{~g}$ hanya $4,8 \%$.

Hasil pengukuran suhu air, kadar DO, $\mathrm{pH}$ air dan $\mathrm{pH}$ sedimen bauksit selama 30 hari di masing-masing bak perlakuan diperlihatkan dalam Gambar 2- Gambar 5. 
Suhu

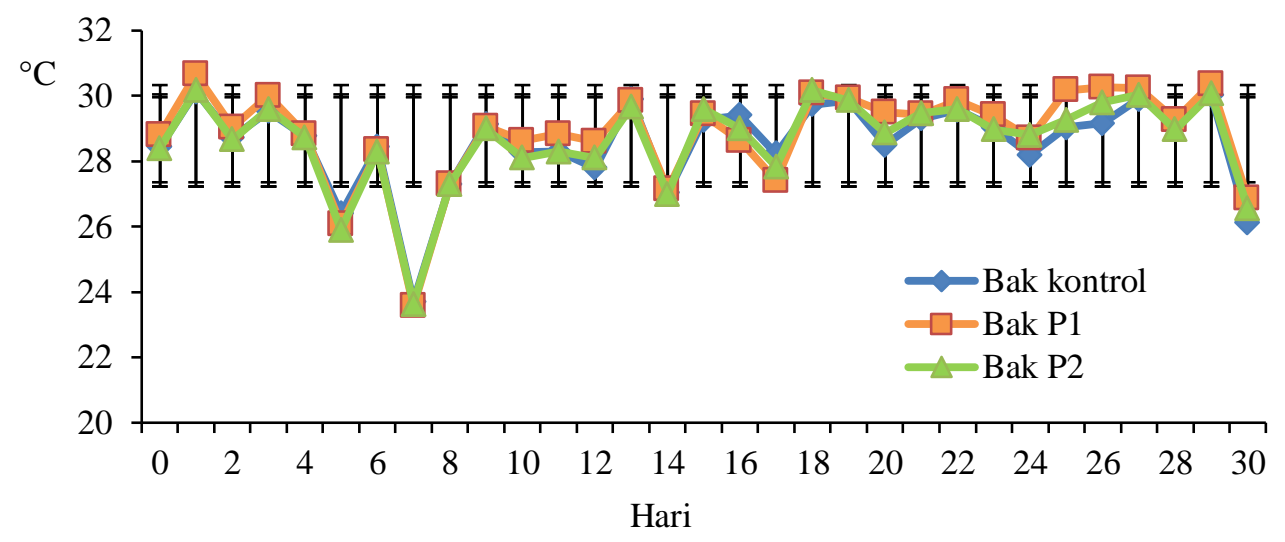

Gambar 2. Suhu air selama penelitian

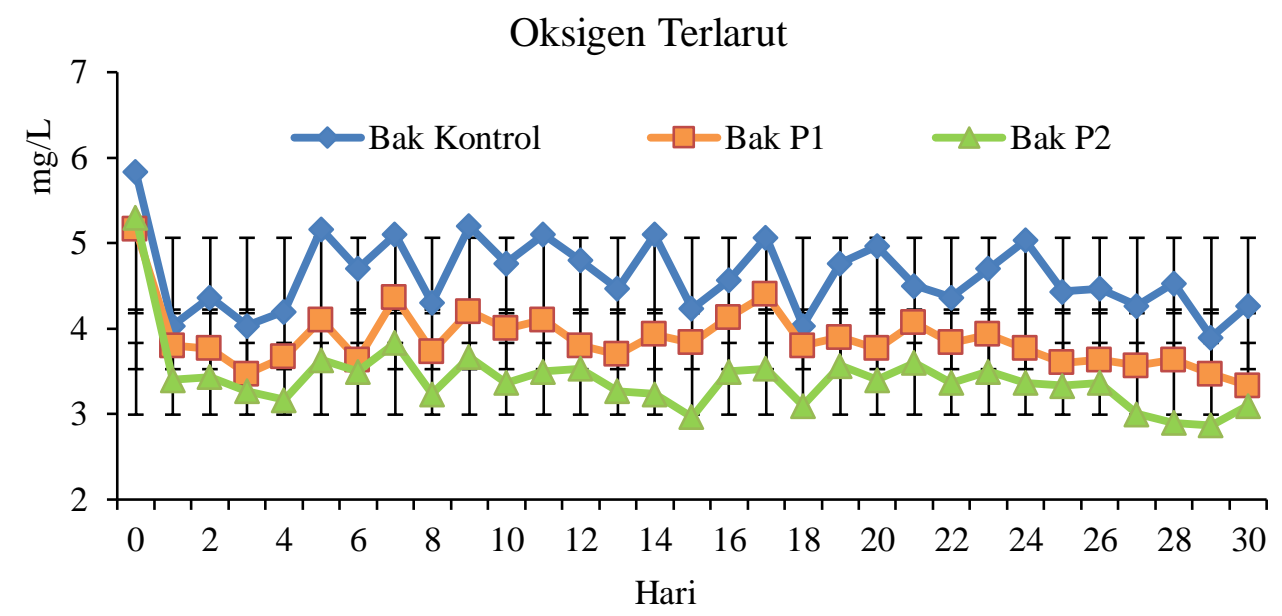

Gambar 3. Konsentrasi oksigen terlarut (DO) selama penelitian

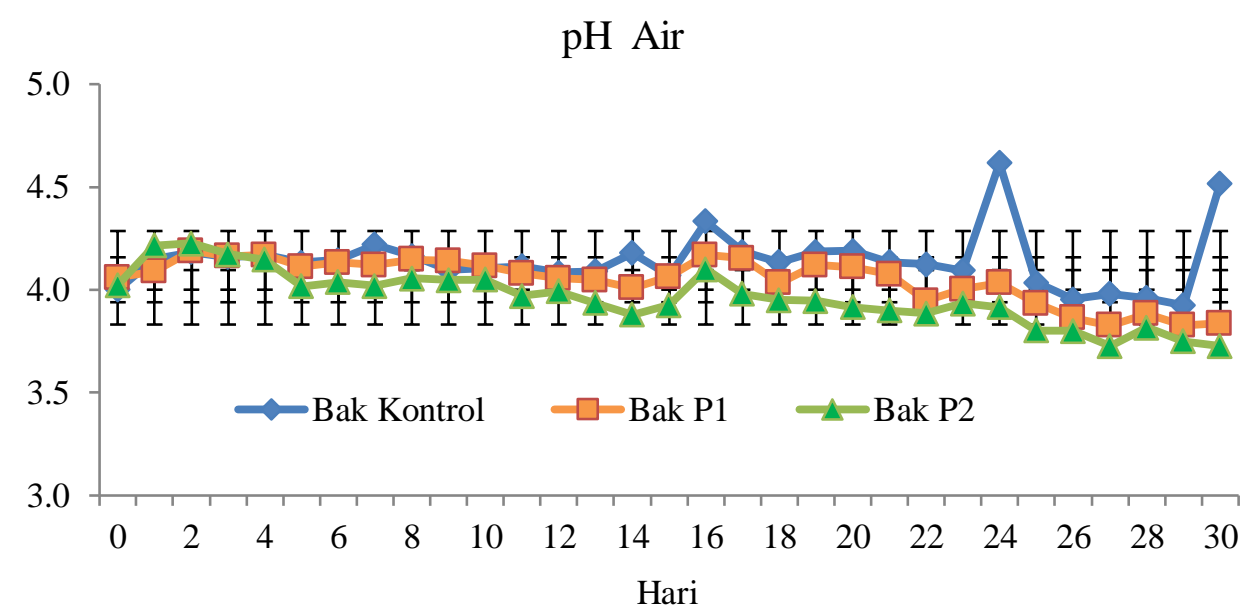

Gambar 4. Nilai pH air selama penelitian 
$\mathrm{pH}$ Sedimen

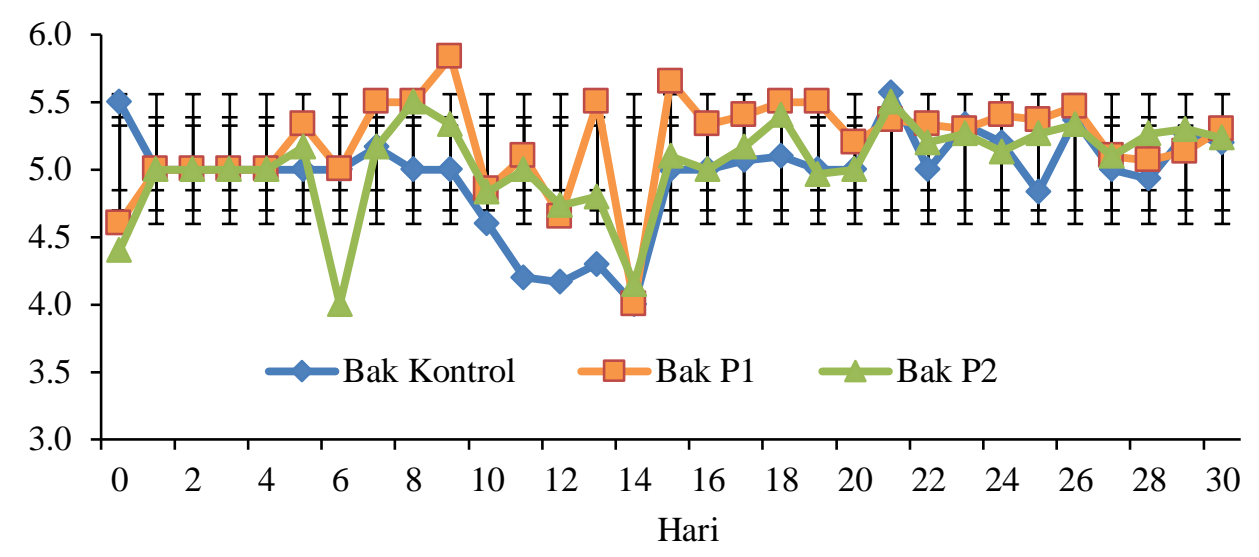

Gambar 5. Nilai pH sedimen selama penelitian

\section{Pembahasan}

Berdasarkan hasil penelitian, terdapat perbedaan yang nyata antara perlakuan biomassa purun $250 \mathrm{~g}$ (P1) dan $500 \mathrm{~g}$ (P2) dalam menyerap besi. Persentase penyerapan besi oleh biomassa purun $500 \mathrm{~g}$ sebesar $80,1 \%$, sedangkan persentase penyerapan oleh biomassa $250 \mathrm{~g}$ hanya sebesar 17,1\% (Tabel 1). Biomassa purun yang dua kali lebih besar menghasilkan penyerapan 4,7 kali lebih banyak. Dalam biomassa $500 \mathrm{~g}$, kemungkinan besar terdapat lebih banyak biomassa akar daripada batang karena menurut Indrayati (2011), dengan biomassa yang sama, akar purun menyerap $\mathrm{Fe}$ sebesar 3,2 kali lebih banyak daripada batang $(2,1 \%$ dibandingkan dengan $0,65 \%$ ). Selain itu, menurut Susilawati dan Indrayati (2016), purun lebih banyak menyerap Fe di bagian akar. Hal ini juga ditunjukkan oleh spesies Eleocharis acicularis yang mampu menyimpan Fe di akar dan toleran terhadap kadar Fe hingga 3,03 mg/kg (Nurfitri et al., 2017) dan $44,8 \mathrm{mg} / \mathrm{kg}$ berat keringnya (Ha et al., 2009). E. acicularis berpotensi mengurangi logam berat di daerah pertambangan (Sakakibara et al., 2013). Kemampuan purun menyerap kontaminan disebut rizofiltrasi, yaitu kemampuan akar menyerap bahan polutan, terutama logam dari air dalam tanah dan mengakumulasinya di akar (Rai, 2009; Widyati, 2009). Akar tumbuhan termasuk purun menyerap besi dalam bentuk ion ferro $\mathrm{Fe}^{2+}$ (Rout \& Sahoo, 2015).

Proses oksidatif Fe pada akar purun, mengirimkan oksigen ke akar sehingga $\mathrm{Fe}^{2+}$ terlarut di tanah menjadi $\mathrm{Fe}^{3+}$ yang dapat mengendap di akar. Purun mengandung senyawa kelat di akar dan batang, sehingga mampu menoleransi konsentrasi $\mathrm{Fe}$ berlebih yang masuk ke dalam jaringan (Napisah \& Annisa, 2019; Susilawati \& Indrayati, 2016). Selain itu, aktivitas fotosintesis oleh akar purun yang menghasilkan oksigen akan meningkatkan oksigen terlarut bagi mikroorganisme di sekitar akar, sehingga bahan pencemar dapat diuraikan menjadi unsur hara yang diserap oleh tumbuhan (Khiatudin, 2003).

Konsentrasi besi terlarut dalam media air mengalami peningkatan pada hari ke-30 dibandingkan hari ke-0 (Tabel 2). Hal ini dimungkinkan karena $\mathrm{Fe}^{2+}$ terlarut yang tinggi pada $\mathrm{pH}$ air rendah (Ashraf et al., 2011). Perubahan konsentrasi besi dapat disebabkan oleh perubahan $\mathrm{pH}$ air, mineral sulfida yang teroksidasi dari sedimen ke air, dan bahan organik. Menurut Henny (2011), oksidasi mineral sulfida dan besi di sedimen dapat melepaskan logam ke air, sehingga keasaman dan konsentrasi logam dalam air meningkat (leaching). Menurut Madaniyah (2016), penurunan atau peningkatan 
konsentrasi logam di air dipengaruhi oleh faktor, antara lain mineral sulfida yang teroksidasi oleh unsur abiotik dan biotik, absorbsi logam oleh tanaman, adsorbsi logam oleh bahan organik, dan biosorbsi logam oleh mikroorganisme.

Reaksi oksidasi mineral sulfida (pirit) menurut Madaniyah (2016) dan Gautama (2012) adalah sebagai berikut:

$$
\begin{aligned}
& 2 \mathrm{FeS}_{2}+7 \mathrm{O}_{2}+2 \mathrm{H}_{2} \mathrm{O} \rightarrow 2 \mathrm{Fe}^{2+}+4 \mathrm{SO}_{4}^{2-}+4 \mathrm{H}^{+} \\
& \mathrm{FeS}_{2}+14 \mathrm{Fe}^{3+}+8 \mathrm{H}_{2} \mathrm{O} \rightarrow 15 \mathrm{Fe}^{2+}+2 \mathrm{SO}_{4}^{2-}+16 \mathrm{H}^{+} \\
& 4 \mathrm{Fe}^{2+}+\mathrm{O}_{2}+4 \mathrm{H}^{+} \rightarrow 4 \mathrm{Fe}^{3+}+2 \mathrm{H}_{2} \mathrm{O} \\
& 4 \mathrm{Fe}^{2+}+\mathrm{O}_{2}+10 \mathrm{H}_{2} \mathrm{O} \rightarrow 4 \mathrm{Fe}(\mathrm{OH})_{3}+8 \mathrm{H}^{+} \\
& 4 \mathrm{FeS}_{2}+15 \mathrm{O}_{2}+14 \mathrm{H}_{2} \mathrm{O} \rightarrow 4 \mathrm{Fe}(\mathrm{OH})_{3}+8 \mathrm{SO}_{4}^{-2}+16 \mathrm{H}^{+}
\end{aligned}
$$

Pirit yang mengalami pelapukan oleh oksigen dan air menghasilkan ion besi ferro, sulfat dan keasaman (1). Kemudian, kehadiran air dan pirit mengubah ion besi ferri menjadi ion besi ferro, sulfat dan keasaman yang lebih banyak (2). Selanjutnya, oksidasi ion besi ferro menjadi ferri (3) dan ion besi ferro dioksidasi dan dihidrolisis menjadi ferri hidroksida (4). Ion ferri hidroksida akan mengendap di dasar (sedimen), sehingga membentuk warna kemerahan pada substrat, dikenal sebagai yellow boy. Reaksi ini bersifat reversibel (bolak-balik), sehingga ion besi mengalami pelarutan dan pengendapan. Reaksi ini merupakan sumber peningkatan atau penurunan ion besi ferri untuk melepaskan asam ke lingkungan. Reaksi kelima merupakan reaksi penggabungan dari ke satu hingga ke empat. Ion sulfat dan keasaman yang terbentuk memengaruhi tingkat keasaman badan air. Ion besi ferri sebagai oksidator kuat dapat melarutkan mineral sulfida, sehingga logam yang terdapat di dalam mineral sulfida terlarut.

Limbah hasil pengolahan bauksit berwarna cokelat kemerahan (red mud) karena banyak mengandung besi atau senyawa $\mathrm{Fe}_{2} \mathrm{O}_{3}$ (Kisnawati \& Suprapto, 2016). Besi di dalam tanah umumnya juga mengandung senyawa $\mathrm{Fe}_{2} \mathrm{O}_{3}$ (Febrina \& Ayuna, 2015). Konsentrasi besi yang tinggi di dalam sedimen bauksit menunjukkan kadar besi ferro $\left(\mathrm{Fe}^{2+}\right)$ yang tinggi. Jaringan akar purun menyerap $\mathrm{Fe}^{2+}$, sehingga konsentrasi besi di dalam sedimen bauksit berkurang. Hal ini didukung oleh Susilawati dan Fahmi (2013), bahwa tanah yang tergenang cenderung berada pada kondisi reduktif. Kondisi tersebut mengurangi laju difusi oksigen, sehingga kadar oksigen rendah. Kelarutan besi di tanah juga dipengaruhi oleh $\mathrm{pH}$ dan kondisi redoks tanah. Zat besi lebih mudah larut dalam tanah dengan $\mathrm{pH}$ rendah, sehingga kadar besi yang tinggi dihasilkan dari tanah yang bersifat asam (Zhang et al., 2012).

Penurunan konsentrasi besi dalam sedimen bak P1 dan P2 (Tabel 3) dimungkinkan karena terjadi penyerapan besi oleh akar purun. Penyerapan ini berupa difusi dari sedimen bauksit ke akar purun. Penurunan konsentrasi besi dalam sedimen di bak kontrol terjadi karena ada pelarutan (leaching) dari sedimen ke air (Tabel 2 dan Tabel 3), selain karena keberadaan mikroorganisme yang berinteraksi dengan lingkungan melalui imobilisasi dan mobilisasi logam. Mikroorganisme yang terdiri dari alga, bakteri, dan fungi dapat menghilangkan bahan pencemar logam (Rai, 2009) karena mempunyai ligan dalam membran sel yang berfungsi untuk mengadsorpsi ion logam (Gadd, 2010).

Menjelang hari ke-30 penelitian, kemungkinan metabolisme biomassa purun mengalami penurunan. Konsentrasi logam besi yang cukup besar dalam media tanam bak P1 dan P2 (Tabel 3) kemungkinan memengaruhi metabolisme purun, sehingga menunjukkan gejala toksisitas. Gejala ini ditandai dengan warna batang purun yang sudah kekuningan pada hari ke-30. Menurut Ulfin dan Widya (2005), konsentrasi logam 
yang berlebih dalam media tanam akan menurunkan metabolisme tanaman dan menyebabkan penampakan fisik tanaman yang menguning.

Berdasarkan hasil penelitian ini, biomassa purun dalam bak P2 efektif menyerap besi dari sedimen bauksit dengan persentase efektivitas penyerapan sebesar $7,6 \%$, sedangkan efektivitas penyerapan biomassa purun dalam bak P1 hanya 4,8\% (Tabel 4). Penyerapan logam oleh tumbuhan diawali dengan penyerapan melalui akar. Akar makrofita memiliki rongga yang lebih besar, sehingga penyerapan ion logam meningkat (Prihatini et al., 2011). Logam yang dapat larut masuk ke membran sel, lalu diangkut melalui jaringan pengangkut xilem dan floem. Molekul kelat yang terdapat dalam jaringan pengangkut berfungsi untuk meningkatkan dan mengefisienkan penyerapan logam. Muatan ion pada logam ditranslokasikan ke bagian lain dan logam dilokalisasi pada sel tertentu (Irhamni et al., 2017). Dalam hal ini, besi yang diangkut jaringan pengangkut ditransportasikan ke jaringan daun (Kruger et al., 2002).

Faktor fisika dan kimia air memengaruhi kelangsungan hidup purun, di antaranya suhu air, kadar oksigen terlarut, $\mathrm{pH}$ air, dan $\mathrm{pH}$ sedimen bauksit. Suhu air di masing-masing bak penelitian mengalami fluktuasi (Gambar 2), namun masih menunjang kehidupan purun dalam melakukan aktivitas fotosintesis. Menurut Widjaja (2004), suhu yang optimal bagi tumbuhan air untuk berfotosintesis berkisar $25-30^{\circ} \mathrm{C}$. Kondisi suhu air selama penelitian masih sesuai dengan suhu alami air di kolam bekas tambang bauksit, yaitu $31,4 \pm 0,1^{\circ} \mathrm{C}$. Hal ini juga didukung oleh Asikin dan Thamrin (2012), bahwa purun tumbuh pada kisaran suhu $30-35{ }^{\circ} \mathrm{C}$.

Kadar oksigen terlarut dalam semua bak penelitian masih sesuai untuk kehidupan purun (Gambar 3). Menurut Stansbury et al. (2008), kadar oksigen terlarut minimum untuk tumbuhan air adalah 2,5 mg/L. Fluktuasi kadar oksigen terlarut dalam penelitian ini kemungkinan karena aktivitas mikrorganisme yang menggunakan oksigen terlarut untuk mendekomposisi bahan organik. Besi mudah berikatan dengan bahan organik, sehingga mikroorganisme dapat mendekomposisi bahan organik tersebut. Menurut Salmin (2005), oksigen terlarut digunakan oleh mikroorganisme untuk respirasi, mendekomposisi bahan organik, dan mengubah senyawa kimia menjadi nutrien.

Nilai $\mathrm{pH}$ air dan $\mathrm{pH}$ sedimen yang rendah dalam penelitian ini masih menunjang kehidupan purun (Gambar 4 dan Gambar 5). Hal ini sejalan dengan hasil penelitian Apriadi dan Ashari (2018) yang mendapatkan $\mathrm{pH}$ air 4,0 di kolam bekas tambang bauksit. Menurut Aryani dan Apriadi (2018), purun merupakan tumbuhan pioner di kolam bekas tambang bauksit. Selain mampu tumbuh di tanah lempung dengan pH sekitar 6-7, purun juga tumbuh di tanah dengan nilai $\mathrm{pH}$ sekitar 3 (Asikin \& Thamrin, 2012). Meskipun $\mathrm{pH}$ air lebih rendah daripada $\mathrm{pH}$ sedimen, namun perbedaan $\mathrm{pH}$ ini tidak signifikan. Nilai $\mathrm{pH}$ air yang sedikit lebih rendah tersebut dikarenakan $\mathrm{pH}$ air berhubungan dengan kelarutan besi (Palar, 2008). Jika terjadi penurunan $\mathrm{pH}$, maka kelarutan senyawa logam akan meningkat. Purun menyerap besi melalui akar, sehingga konsentrasi besi di sedimen bauksit berkurang dan nilai $\mathrm{pH}$ menjadi lebih tinggi daripada $\mathrm{pH}$ air yang cenderung lebih asam.

\section{Kesimpulan}

Perlakuan variasi biomassa purun 250 $\mathrm{g}$ dan $500 \mathrm{~g}$ menunjukkan perbedaan yang nyata dalam menyerap besi selama 30 hari penelitian. Persentase penyerapan biomassa purun $500 \mathrm{~g}$ yang 4,7 kali lebih banyak daripada biomassa purun $250 \mathrm{~g}$ menunjukkan bahwa biomassa purun $500 \mathrm{~g}$ mengandung lebih banyak akar daripada batang. Penelitian ini mengonfirmasi bahwa akar purun lebih efektif dalam menyerap dan menyimpan logam besi. 


\section{Ucapan Terima Kasih}

Ucapan terima kasih disampaikan kepada pihak Laboratorium FIKP UMRAH dan BTKLPP Kelas I Batam yang telah membantu dalam analisis konsentrasi $\mathrm{Fe}$. Penulis juga mengucapkan terima kasih kepada Rani, Andreas, Adi, Siti, Iqbal, Devi, Nurul, Irvan, Nurria, dan Yohanes yang telah membantu penelitian ini.

\section{Referensi}

Ainiyah S, Lestari I, Andini A. 2018. Hubungan Antara Kadar Besi (Fe) Air Tambak Terhadap Kadar Besi (Fe) pada Daging Ikan Nila (Oreochromis niloticus) dan Ikan Bandeng (Chanos chanos) di Kecamatan Jabon, Sidoarjo. Jurnal Sain Health 2(2): 21-28

Amelia RA, Rachmadiarti F, Yuliani. 2015. Analisis Kadar Logam Berat $\mathrm{Pb}$ dan Pertumbuhan Tanaman Padi di Area Persawahan Dusun Betas, Desa Kapulungan, Gempol-Pasuruan. Lentra Berkala Ilmiah Biologi 4(3): 187-191

Amrin, Ardilla D. 2013. Analisis Besi (Fe) dan Aluminium (Al) dalam Tanah Lempung Secara Spektrofotometri Serapan Atom. Prosiding Semirata FMIPA Universitas Lampung, 17-22

AOAC. 1990. Official Methods of Analysis. Association of Official Analytical Chemistry 15th Edition. Arlington: USA

APHA. 1999. Standard Methods for the Examination of Water and Wastewater. Water Environment Federation: USA

Apriadi T, Ashari IH. 2018. Struktur Komunitas Fitoplankton pada Kolong Pengendapan Limbah Tailing Bauksit di Senggarang, Tanjungpinang. Majalah Ilmiah Biologi Biosfera - A Scientific Journal 35(3): 145-152

Ariyani D, Syam R, Utami B, Nirtha RI. 2014. Kajian Absorpsi Logam Fe dan Mn oleh Tanaman Purun Tikus (E. dulcis) pada Air Asam Tambang Secara Fitoremediasi. Sains dan Terapan Kimia 8(2): 87-93
Aryani R, Apriadi T. 2018. Inventory of Epiphytes Aquatic Microfungi in Pond of Tailing Bauxite in Tanjungpinang, Bintan Island, Riau Islands Province. Omni-Akuatika 14(3): 106-111

Ashraf M, Maah MJ, Yusoff I. 2011. Heavy Metals Accumulation in Plants Growing in Ex Tin Mining Catchment. Int. J. Environ. Sci. Tech. 8(2): 401-416

Asikin S, Thamrin M. 2012. Manfaat Purun Tikus (Eleocharis dulcis) pada Ekosistem Sawah Rawa. Jurnal Litbang Pertanian Balai Penelitian Pertanian Lahan Rawa 3(1): 35-42

Badan Pusat Statistik Kota Tanjungpinang. 2018. Statistik Daerah Kota Tanjungpinang

Becker M, Asch F. 2005. Iron Toxicity in Rice Conditions and Management Concepts. Journal Plant Nutrition Soil Science 168: 558-573

Cadmus P, Brinkman SF, Melynda KM. 2018. Chronic Toxicity of Ferric Iron for North American Aquatic Organisms: Derivation of a Chronic Water Quality Criterion Using Single Species and Mesocosm Data. Arch. Environ. Contam. Toxicol. 74(4): 605-615. DOI: 10.1007/s00244-018-0505-2

Effendi H. 2003. Telaah Kualitas Air bagi Pengelolaan Sumberdaya dan Lingkungan Perairan. Kanisius. Yogyakarta

Febrina L, Ayuna A. 2015. Studi Penurunan Kadar Besi (Fe) dan Mangan (Mn) dalam Air Tanah Menggunakan Saringan Keramik. Jurnal Teknologi 7(1): 35-44

Gadd GM. 2010. Metals, Minerals and Microbes: Geomicrobiology and Bioremediation. Microbiology 156: 609-643

Gautama RS. 2012. Pengelolaan Air Asam Tambang. Bimbingan Teknis Reklamasi dan Pasca tambang pada Kegiatan Pertambangan Mineral dan Batubara. Ditjen Mineral dan Batubara

Ha N, Sakakibara M, Rie S, Sera K. 2009. The Potential of Eleocharis acicularis for Phytoremediation: Case Study at an 
Abandoned Mine Site. Clean 37(3): 203-208

Henny C. 2011. Kolong Bekas Tambang Timah di Pulau Bangka: Permasalahan Kualitas Air dan Alternatif Solusi untuk Pemanfaatan. Oseanologi dan Limnologi di Indonesia 37(1): 119-138

Herliyanto, Budianta, Hermansyah. 2014. Toksisitas Logam Besi (Fe) pada Ikan Air Tawar. Jurnal Penelitian Sains 17(1): 26-34

Indrayati L. 2011. Purun Tikus Berpotensi Perbaiki Kualitas Air di Rawa Pasang Surut. Agroinovasi Sinar Tani Edisi 6-12. No. 3400 Tahun XLI

Irhamni, Pandia S, Purba E, Hasan W. 2017. Kajian Akumulator Beberapa Tumbuhan Air dalam Menyerap Logam Berat Secara Fitoremediasi. Jurnal Serambi Engineering 1(2): 75-84

Khiatuddin M. 2003. Melestarikan Sumberdaya Air dengan Teknologi Rawa Buatan. Gadjah Mada University Press

Kisnawati RD, Suprapto. 2016. Pemisahan Alumina pada Residu Bauksit (Red Mud) yang Berasal dari Riau dengan Metode Sintering Sodalime. Jurnal Sains dan Seni ITS 5(2): 160-163

Kruger C, Berkowitz O, Stephan Udo, Hell R. 2002. A Metal-Binding Member of The Late Embryogenesis Abundant Protein Family Transports Iron in The Phloem of Ricinus communis. The Journal of Biological Chemistry 277(28): 25062-25069

Kurniawati D, Afkar Z, Khairiyah N. 2012. Penentuan Kandungan Besi $(\mathrm{Fe})$ dan Magnesium (Mg) dalam Bijih Mangan secara Spektrofotometri Serapan Atom. Prosiding Semirata BKS - PTN MIPA, 76-80

Kusmanto, Fauzi A, Wibowo GS, Aji B. 2019. Pengelolaan Air dalam Menunjang Kegiatan Pencucian pada Proses Penambangan Bauksit. Prosiding TPT XXVIII Perhapi, 739

Madaniyah. 2016. Efektivitas Tanaman Air dalam Pembersihan Logam Berat pada
Air Asam Tambang. Tesis. Institut Pertanian Bogor

Mohari H. 2013. Hentikan Penambangan Bauksit.

https://www.antarafoto.com/mudik/v13 64460920/hentikan-penambanganbauksit

Nagajyoti PC, Lee KD, SreeKanth TVM. 2010. Heavy Metals, Occurrence and Toxicity for Plants: A Review. Environmental Chemistry Letter 8: 199216

Napisah K, Annisa W. 2019. Peran Purun Tikus (Eleocharis dulcis) sebagai Penyerap dan Penetral Fe di Lahan Rawa Pasang Surut. Jurnal Sumberdaya Lahan 13(1): 53-59

Nurfitri AG, Masayuki S, Koichiro S. 2017. Phytoremediation of Heavy MetalPolluted Mine Drainage by Eleocharis acicularis. Environmental Science Indian Journal 13(1): 131

Nurhaini R, Affandi A. 2016. Analisa Logam Besi (Fe) di Sungai Pasar Daerah Belangwetan Klaten dengan Metode Spektrofotometri Serapan Atom. Jurnal Ilmiah Manuntung 2(1): 39-43

Prayudi M. 2015. Fitoremediasi Tanah Tercemar Logam Cr dengan Tumbuhan Akar Wangi pada Media Tanah Berkompos. Universitas Hasanudin. Makassar

Palar. 2008. Pencemaran dan Toksikologi Logam Berat. Rhineka Cipta: Jakarta

Prihatini NS, Krisdianto, Setyorini A, Azizah N, Khameni S, Astuti DT. 2011. Potensi Purun Tikus (Eleocharis) sebagai Biofilter. Proceedings Environmental Talk, 154-165

Rohmana, Djunaedi E, Pohan M. 2007. Inventarisasi Bahan Galian pada Bekas Tambang di Daerah Pulau Bintan, Provinsi Kepulauan Riau. Prosiding Pemaparan Hasil Kegiatan Lapangan dan Non Lapangan Tahun 2007. Pusat Sumberdaya Geologi

Rout GR, Sahoo S. 2015. Role of Iron in Plant Growth and Metabolism. Reviews in Agricultural Sciene 3: 1-24 
Rai PK. 2009. Heavy Metal Phytoremediation from Aquatic Ecosystems with Special Reference to Macrophytes. Critical Reviews in Environmental Science and Technology 39: 697-753

Salmin. 2005. Oksigen Terlarut (DO) dan Kebutuhan Oksigen Biologi (BOD) sebagai Salah Satu Indikator untuk Menentukan Kualitas Perairan. Oseana 30(3): 21-26

SNI 6989.4:2009. Air dan Air Limbah Bagian 4: Cara Uji Besi Fe Secara Spektrofotometri Serapan Atom

Stansbury J, Kozimor L, Admiraa D, Dove E. 2008. Water Quality Modeling of The Effects of Macrophytes on Dissolved Oxygen in A Shallow Tailwater Reservoir. Lake and Reservoir Management 24: 339-348

Sudiyani Y, Ardeniswan, Rahayuningwulan D. 2011. Determinasi Arsen (As) dan Merkuri $(\mathrm{Hg})$ dalam Air di kolam Bekas Tambang Timah (Air Kolong) di Propinsi Bangka Belitung. Ecolab. 5(2): 55-67

Sakakibara M, Sugawara M, Sano S, Sera K. 2013. Phytoremediation of Heavy Metal-Contaminated River Water by Aquatic Macrophyte Eleocharis Acicularis in a Mine Site, Southwestern Japan. NMCC Annual Report 20: 226-33

Susilawati A, Indrayati L. 2016. Teknologi Penurunan Kadar Fe Air Sawah Pasang
Surut Melalui Penggunaan Biofilter Purun Tikus (Eleocharis dulcis). Berita Biologi 15(1): 1-6

Susilawati A, Fahmi A. 2013. Dinamika Besi pada Tanah Sulfat Masam yang Ditanami Padi. Jurnal Sumberdaya Lahan 7(2): 67-75

Ulfin I, Widya W. 2005. Studi Penyerapan Kromium dengan Kayu Apu (Pistia stratiotes L). Jurnal Akta Kimindo 1(1): 41-48

Widjaja F. 2004. Tumbuhan Air. Institut Pertanian Bogor. Bogor

Widyati E. 2009. Kajian Fitoremediasi sebagai Salah Satu Upaya Menurunkan Akumulasi Logam Akibat Air Asam Tambang pada Lahan Bekas Tambang Batubara. Tekno Hutan Tanaman 2(2): 67-75

Zhang C, Ge Y, Yao H, Chen X, Hu M. 2012. Iron Oxidation-Reduction and Its Impacts on Cadmium Bioavailability in Paddy Soils: A Review. Front. Environment Science Engineering 6(4): 509-517

Zulfikar A, Azizah D, Melani WR. 2015. Perbandingan Kadar Logam Berat Limbah Cair Bauksit di Sei Carang, Kelurahan Kampung Bugis, Kabupaten Bintan. Universitas Maritim Raja Ali Haji. Tanjung Pinang 